\title{
STUDI PENGETAHUAN DAN SIKAP TINDAKAN MAYARAKAT TERHADAP SANITASI LINGKUNGAN DI PANTAI BALLONA KECAMATAN TALIWANG KABUPATEN SUMBAWA BARAT
}

\author{
NI MADE NIA BUNGA SURYA DEWI \\ Program Studi Teknik Sipil K. Mataram UNMAS Denpasar \\ e-mail : myname.niabunga@gmail.com
}

\begin{abstract}
ABSTRAK
Sanitasi merupakan suatu pengendalian seluruh faktor lingkungan fisik manusia yang dapat/ bisa menimbulkan akibat buruk terhadap kehidupan manusia, baik fisik atau juga mental. Kebersihan lingkungan sangat erat kaitannya dengan kesehatan masyarakat sekitarnya, berbagai permasalahan sering disebabkan kurangnya informasi yang diterima oleh masyarakat. Hasil dari penelitian yang menggunakan metode deskriptif ini adalah untuk mengetahui gambaran pengetahuan, sikap dan tindakan masyarakat di pesisir Pantai Ballona Kecamatan Taliwang, Kabupaten Sumbawa Barat tentang sanitasi lingkungan, yang dimana dilaksanakan pada bulan September - Oktober 2020 di Kecamatan Taliwang sebesar 97 KK dan metode pengumpulan data yang dipergunakan adalah penggunaan metode pengamatan (observasi) dan wawancara (kuesioner).

Masyarakat yang bermukim di pesisir Pantai Ballona Kecamatan Taliwang yang memiliki pengetahuan baik mengenai sanitasi sejumlah 39 responden $(40,2 \%)$, yang memiliki pengetahuan cukup sejumlah 51 responden $(52,6 \%)$ dan yang memiliki pengetahuan kurang baik mengenai sanitasi sejumlah 7 responden (7,2\%). Sedangkan masyarakat pesisir Pantai Ballona Kecamatan Taliwang yang mempunyai sikap positif terhadap sanitasi sejumlah 46 orang $(47,4 \%)$ dan responden negatif sejumlah $51(52,6 \%)$ orang serta 0 responden yang mempunyai tindakan baik mengenai sanitasi lingkungan. Masyarat di pesisir pantai Kecamatan Taliwang yang memiliki tindakan cukup sejumlah 34 responden $(35,1 \%)$ dan yang memiliki tindakan kurang baik sejumlah 63 responden $(64,9 \%)$.
\end{abstract}

Kata Kunci: pengetahuan, sikap, tindakan, sanitasi lingkungan

\section{ABSTRACT}

Sanitation is a control over all factors of the human physical environment which can / can have adverse effects on human life, both physically and mentally. Environmental cleanliness is closely related to the health of the surrounding community, various problems are often caused by a lack of information received by the community. The results of research using this descriptive method are to describe the knowledge, attitudes and actions of the community on the coast of Ballona beach Taliwang District, West Sumbawa Regency regarding environmental sanitation, which was carried out in September - October 2020 in Taliwang District for 97 respondents and data collection methods. which is used is the use of methods of observation (observation) and interviews (questionnaire and SPSS as a research instrument.

People who live on the coast of Ballona beach Taliwang district which have good knowledge about sanitation are 39 respondents (40.2\%), which has sufficient knowledge of 51 respondents $(52.6 \%)$ and 7 respondents (7,2\%) who have poor knowledge of sanitation. Meanwhile, the coastal communities of Ballona beach Taliwang District who had positive attitudes towards sanitation were 46 people (47.4\%) and negative respondents were $51(52.6 \%)$ people and 0 respondents who had good actions regarding environmental sanitation. There were 34 respondents $(35.1 \%)$ who had sufficient action in the coastal area of the coast of Taliwang District and 63 respondents (64.9\%) had unfavorable actions.

Keywords: knowledge, action, attitude, environmental sanitation 


\section{PENDAHULUAN}

Secara umum kondisi sanitasi Kabupaten Sumbawa Barat terkait sistem pengolahan air limbah domestik masih dikelola secara on-site system (setempat). Hasil studi Environmental Health Risk Assessment (EHRA) tahun 2016, sistem ini meliputi tangki septik sebesar 83\%, pipa sewer 3,20\%, cubluk 4,30\% dan selebihnya dibuang disungai, sawah kebun/ tanah lapang dan drainase 9,57\%. Kabupaten Sumbawa Barat terbagi menjadi 8 kecamatan. Untuk Kecamatan Taliwang sendiri dibagi menjadi 15 Kelurahan/ Desa dengan luas wilayah 37.593 Ha. Data penduduk di Kecamatan Taliwang per tahun 2015 sejumlah 49.795 jiwa dan jumlah penduduk miskin adalah 2.974 Rumah Tangga (KK) (Pemutakhiran SSK KSB, 2016).

Sanitasi adalah pendekatan untuk mengubah perilaku higienis dan saniter melalui pemberdayaan masyarakat dengan cara mendorong perubahan perilaku higiene dan sanitasi individu atau masyarakat atas kesadaran sendiri dengan menyentuh perasaan, pola pikir, perilaku, dan kebiasaan individu atau masyarakat.

Hal mendasar yang menyebabkan sulitnya pelaksanaan upaya sanitasi lingkungan di daerah pesisir dan kepulauan ialah rendahnya pemahaman mengenai pentingnya upaya sanitasi lingkungan serta kemampuan finansial yang kurang mencukupi bagi setiap rumah tangga untuk mengupayakan sanitasi lingkungan rumah tangga yang memenuhi syarat. Kebersihan lingkungan sangat erat kaitannya dengan kesehatan masyarakat sekitarnya, berbagai permasalahan sering disebabkan kurangnya informasi yang diterima oleh masyarakat pesisir pantai.

Tantangan pembangunan sanitasi di Indonesia adalah masalah sosial budaya dan perilaku penduduk yang terbiasa buang air besar (BAB) disembarang tempat, khususnya ke badan air yang juga digunakan untuk mencuci dan mandi (Permenkes RI Nomor 3 Tahun 2014 tentang STBM). Sesuai dengan data sekunder yang diperoleh pada Kecamatan Taliwang jumlah rumah tangga yang memiliki jamban sebanyak $588 \mathrm{KK}$ dengan presentase 4,72\%, BABs (BAB langsung di kebun, kolam, laut, sungai, sawah/ lading, dsb) sebanyak $133 \mathrm{KK}$ dengan presentase 1,07\%, yang memiliki sarana tangki septik individual sebanyak $9.521 \mathrm{KK}$ dengan presentase $76,48 \%$. Sumber air bersih yang tersedia di Kecamatan Taliwang sesuai dengan jumlah keluarga yang diperiksa $23.204 \mathrm{KK}$, yang mempunyai akses air bersih sebanyak 4.641 KK dengan presentase 9,32\% (Pemutakhiran SSK KSB, 2016)

\section{Rumusan Masalah}

Adapun rumusan masalah dalam penelitian ini yaitu "Bagaimana pengetahuan, sikap dan tindakan masyarakat di pesisir pantai Ballona tentang sanitasi lingkungan?".

\section{Tujuan Dan Penelitian}

Rendahnya kesadaran dari masyarakat di pesisir pantai terhadap sanitasi lingkungan karena pada umumnya masyarakat pesisir Pantai Ballona hanya memikirkan dan fokus untuk berusaha memenuhi kebutuhan keluarga, tujuan penelitian ini untuk mengetahui pengetahuan, sikap dan tindakan masyarakat di pesisir pantai Ballona tentang sanitasi lingkungan.

Manfaat dari penelitian ini adalah diharapkan untuk pada masa yang akan datang kehidupan masyarakat pesisir di Pantai Ballona dapat memiliki pengetahuan serta tindakan sanitasi dan higienitas yang baik dan layak.

\section{METODOLOGI PENELITIAN}

Jenis penelitian ini adalah bersifat deskriptif yang menggambarkan tentang pengetahuan, sikap dan tindakan tentang sanitasi lingkungan masyarakat pesisir Pantai Ballona KecamatanTaliwang.

Penelitian ini dilaksanakan di Pesisir Pantai Ballona Kecamatan Taliwang pada bulan September - Oktober 2020. Penentuan populasi berdasarkan data sekunder yang diperoleh dari pengambilan data di kantor Desa Kertasari pada tanggal 18 September 2020 dengan jumlah sampel sebanyak 97 responden. Metode pengumpulan data yang digunakan dalam penelitian ini menggunakan metode pengamatan (observasi) dan wawancara (kuesioner). 


\section{HASIL DAN PEMBAHASAN}

Tabel 1. Distribusi Karakteristik Responden

\begin{tabular}{|c|c|c|c|}
\hline \multicolumn{2}{|c|}{ Karakteristik Responden } & $\mathrm{n}$ & $\%$ \\
\hline \multirow{2}{*}{$\begin{array}{l}\text { Jenis } \\
\text { Kelamin }\end{array}$} & Laki-laki & 34 & 35,1 \\
\hline & Perempuan & 63 & 64,9 \\
\hline \multirow{4}{*}{ Umur } & $20-30$ & 19 & 19,6 \\
\hline & $31-40$ & 24 & 24,7 \\
\hline & $41-50$ & 27 & 27,8 \\
\hline & $>50$ & 27 & 27,8 \\
\hline \multirow{8}{*}{ Pekerjaan } & Buruh & 6 & 6,2 \\
\hline & Montir & 2 & 2,1 \\
\hline & Nelayan & 58 & 59,8 \\
\hline & Pedagang & 11 & 11,3 \\
\hline & PNS & 1 & 1,0 \\
\hline & Supir & 2 & 2,1 \\
\hline & Swasta & 3 & 3,1 \\
\hline & Tani & 14 & 14,4 \\
\hline \multirow{5}{*}{$\begin{array}{l}\text { Tingkat } \\
\text { Pendidikan }\end{array}$} & Tidak tamat SD & 12 & 12,4 \\
\hline & Tamat SD & 36 & 37,1 \\
\hline & Tamat SMP & 27 & 27,8 \\
\hline & Tamat SMA/ SMK & 21 & 21,6 \\
\hline & Tamat Perguruan Tinggi & 1 & 1,0 \\
\hline
\end{tabular}

Dari hasil yang didapatkan responden lebih banyak yaitu berjenis kelamin perempuan 63 responden $(64,9 \%)$ dibandingkan laki-laki 34 responden $(35,1 \%)$. Responden berdasarkan kelompok umur yaitu umur 41-50 tahun dan > 50 tahun dengan jumlah 27 responden $(27,8 \%)$ yang merupakan kepala rumah tangga atau ibu rumah tangga yang dianggap mengetahui kebiasaan dan keadaan lingkungan sekitar rumah. Jumlah pekerjaan yang paling banyak yaitu nelayan sejumlah 58 responden (59,8\%). Dilihat dari tingkat pendidikan terakhir, tamat SD 36 responden $(37,1 \%)$ yaitu kelompok umur $41-50$ tahun (29 responden) dan > 50 tahun (22 responden) dengan jumlah kedua kelompok umur tersebut adalah (53 $\%$ ) yang merupakan kepala rumah tangga atau ibu rumah tangga yang dianggap tahu tentang kebiasaan dan keadaan lingkungan sekitar rumah. Jumlah pekerjaan yang paling banyak yaitu nelayan 58 responden $(59,8 \%)$ dengan tingkat pendidikan terakhir tamat SD 36 responden $(37,1 \%)$.

Tabel 2. Tabel Distribusi Responden

\begin{tabular}{|c|c|c|c|}
\hline & & $\mathrm{n}$ & $\%$ \\
\hline \multirow{3}{*}{ Pengetahuan } & Baik & 39 & 40,2 \\
\hline & Cukup & 51 & 52,6 \\
\hline & Kurang & 7 & 7,2 \\
\hline \multirow{2}{*}{ Sikap } & Positif & 46 & 47,4 \\
\hline & Negatif & 51 & 52,6 \\
\hline \multirow{3}{*}{ Tindakan } & Baik & 0 & 0 \\
\hline & Cukup & 34 & 35,1 \\
\hline & Kurang Baik & 63 & 64,9 \\
\hline \multicolumn{2}{|c|}{ Total } & 97 & 100 \\
\hline
\end{tabular}

Pada tabel 2, Distribusi Responden berdasarkan pertanyaan tentang pengetahuan, sikap dan tindakan, dapat dilihat bahwa pada hal pengetahuan menunjukan bahwa dari 97 responden yang menjadi sampel, responden yang memiliki pengetahuan baik dari 16 butir pertanyaan pada kuesioner mengenai pengetahuan yang diberikan sejumlah 39 responden (40,2\%), yang memiliki pengetahuan cukup sejumlah 51 responden $(52,6 \%)$ dan yang memiliki pengetahuan kurang sejumlah 7 responden $(7,2 \%)$. Pengetahuan apabila penerimaan perilaku baru atau adopsi perilaku melalui proses yang didasari oleh pengetahuan, kesadaran dan sikap yang positif, maka perilaku tersebut akan bersifat langgeng (long lasting) daripada perilaku yang tidak didasari oleh pengetahuan (Notoatmodjo, 2007). Pada distribusi responden berdasarkan sikap menunjukkan bahwa 97 responden yang menjadi sampel, dimana yang mempunyai sikap positif dari 15 pertanyaan kuesioner mengenai sikap masyarakat setempat terhadap sanitasi lingkungan sejumlah 46 responden $(47,4 \%)$ dan sikap negatif sejumlah 51 responden $(52,6 \%)$. dan tindakan. Perilaku merupakan respon/reaksi seorang individu terhadap stimulus yang berasal dari luar maupun dari dalam dirinya (Notoatmojo, 2010). 
Berbeda dengan pengetahuan, masyarakat pesisir Pantai Ballona memiliki sikap yang tidak selaras dengan pengetahuan yang mereka miliki terhadap sanitasi lingkungannya, hal ini disebabkan oleh situasi lain yang tidak diteliti lebih jauh pada di lingkungan responden seperti rumah semi permanen, berdekatan, dan banyaknya penghuni dalam satu rumah. Pada tindakan menunjukan bahwa dari 97 responden yang menjadi sampel, responden yang memiliki tindakan kurang baik sejumlah 63 responden $(64,9 \%)$ dan 34 responden $(35,1 \%)$ mempunyai tindakan cukup baik.

Hasil dalam penelitian ini menunjukan bahwa tingkat pengetahuan dari masyarakat sebagian besar adalah baik tetapi tindakan/ aksi untuk melakukan sanitasi yang baik adalah kurang baik, hal ini disebabkan karena masyarakat yang tinggal di pesisir Pantai Ballona merupakan masyarakat pendatang yang bermata pencaharian sebagai pedagang yang berjualan di pasar tradisional Tana Mira Taliwang, sehingga rumah yang dibangun adalah rumah sementara yang terbuat dari tripleks, seng dan kayu. Hal ini dilakukan karena lingkungan rumah yang berada tepat di pantai sehingga pada saat air pasang maka rumah yang dibangun akan tenggelam oleh air laut, mengakibatkan tripleks, seng dan kayu terhanyut dan mencemari laut. Pada saat air surut tripleks, seng dan kayu yang hanyut oleh air pasang akan tertinggal di pantai sehingga membuat pantai menjadi kotor. Keadaan inipun menyebabkan sehingga jamban tidak dapat disediakan oleh setiap rumah, sehingga masyarakat yang akan melakukan BAB harus ke MCK umum atau dipinggir laut.

Sesuai pengamatan (observasi) selama penelitian di Pantai Ballona yang terjadi adalah masyarakat kurang memanfaatkan MCK umum yang disediakan oleh pemerintah, hal ini karena jumlah persediaan air bersih dan MCK tidak dapat menampung jumlah masyarakat pesisir Pantai Ballona sehingga masyarakat yang akan $\mathrm{BAB} / \mathrm{MCK}$ memilih melakukannya di pinggir pantai. Oleh karenanya dapat dikatakan bahwa tingkat pengetahuan dari sebagian masyarakat sudah baik tetapi dalam tindakannya tidak melakukan sanitasi lingkungan yang baik.

\section{PENUTUP}

\section{Simpulan}

Masyarakat pesisir Pantai Ballona Kecamatan Taliwang yang memiliki pengetahuan baik tentang sanitasi berjumlah 40 responden $(40,4 \%)$, yang memiliki pengetahuan cukup berjumlah 53 responden $(53,5 \%)$ Masyarakat pesisir Pantai Ballona yang bersikap positif berjumlah 49 responden $(49,5 \%)$ dan negatif 50 responden (50,5\%) 3. Masyarakat pesisir Pantai Ballona Kecamatan Taliwang yang mempunyai tindakan baik tentang sanitasi lingkungan 0 responden, yang memiliki tindakan cukup 39 responden $(39,4 \%)$ dan yang memiliki tindakan kurang baik berjumlah 60 responden $(60,6 \%)$ an yang memiliki pengetahuan kurang baik tentang sanitasi berjumlah 6 responden $(6,1 \%)$.

\section{Saran}

1. Perlunya kerjasama lintas program dan lintas sektoral baik dari pemerintah maupun masyarakat untuk menanggulangi masalah sanitasi lingkungan. Penanggulangan dapat melalui pendidikan kesehatan lingkungan yaitu penyuluhan sanitasi lingkungan kepada masyarakat serta pengawasan dan monitoring secara berkala dari puskesmas untuk mengetahui keadaan sanitasi lingkungan masyarakat.

2. Disarankan kepada Pemerintah, khususnya Lurah dan perangkat kelurahan yang ada untuk lebih memperhatikan dan memotivasi masyarakat yang tinggal di sepanjang pesisir Pantai Ballona agar menjaga sanitasi lingkungannya seperti tidak membuang sampah disepanjang pantai dan memenfaatkan fasilitas MCK umum yang sudah disediakan oleh pemerintah.

3. Perlunya dilakukan penelitian lebih lanjut untuk mengetahui faktor-faktor yang mempengaruhi keadaan sanitasi lingkungan masyarakat pesisir Pantai Ballona KecamatanTaliwang.

\section{DAFTAR PUSTAKA}

Peraturan Menteri Kesehatan Republik Indonesia Nomor 3 Tahun 2014. Sanitasi Total Berbasis Masyarakat.

Pemerintah Kabupaten Sumbawa Barat. 2016. Data Pemutakihiran Strategi Sanitasi.

Notoatmodjo, S. 2007. Kesehatan Masyarakat Ilmu dan Seni. Jakarta : Rineka Cipta.

Notoatmodjo, S. 2010. Metodologi Penelitian Kesehatan. Jakarta : Rineka Cipta. 